\title{
Language variation: Code-mixing and code-switching in Pakistani commercials
}

\author{
Mehvish Riaz ${ }^{\mathrm{a}} *$ \\ ${ }^{a}$ University of Engineering and Technology, Lahore, Pakistan
}

\section{APA Citation:}

Riaz, M. (2019). Language variation: Code-mixing and code-switching in Pakistani commercials. Journal of Language and Linguistic Studies, 15(2), 411-419.

Submission date: $4 / 1 / 2018$

Acceptance date: 10/2/2019

\begin{abstract}
English as an international language has left its impact on all the languages being spoken in the world. This impact has led to a world-wide language variation on a large scale. This variation can be evidently observed in the form of code-mixing and code-switching. The study explores and analyzes the frequency of code-mixing in the TV ads broadcasted in Pakistan so as to determine the level of variation that took place in Urdu due to English. Seventy commercials that have been shown during the years 2011-2015 have randomly been selected and the frequency of English words has been checked. The results show that so far as the language of commercials is concerned, Urdu has clearly been influenced by English due to multiple reasons such as fashion, ease and technological advancements etc.
\end{abstract}

(C) 2019 JLLS and the Authors - Published by JLLS.

Keywords: language variation; commercials; code-mixing; code-switching

\section{Introduction}

The study aims at doing a stylistic analysis of the TV ads broadcasted in Pakistan on the basis of code-mixing and code-switching. It endeavors to pinpoint the variation in Urdu caused by the influence of English. Media is a vital source of influencing not only the mindsets of people but also their behavioral and linguistic patterns. The language of media stamps a remarkable effect on the language being spoken by its viewers, readers or listeners. The study explores the extent to which code-mixing or codeswitching is employed in the TV ads broadcasted on the famous Pakistani TV channels such as GEO, ARY and HUM TV. Code-mixing may be defined as shifting back and forth between two languages, especially in a solitary discourse (Skiba, 1997, p. 47). "Mixing' means the transfer of the units of code A into code B at intersentential and intrasentential levels" (Kachru, 1986, cited in Mushtaq \& Zahra, 2012, p. 429).

"Code-switching refers to the switch or shift from one language to the other which involves longer stretches of language as the clause or sentence boundary; while generally code-mixing does not involve shifts beyond smaller units of language such as words or phrases" (Mushtaq \& Zahra, 2012, p. 429).

\footnotetext{
${ }^{*}$ Corresponding author. Tel.: +0-000-000-0000

E-mail address: mehvishriaz@ymail.com
} 
As an international language, English not only serves the role of lingua franca in non-Englishspeaking countries (Shooshtari \& Allahbakhsh, 2013) but also broadens the lexicon of the languages spoken world-wide. English, as a "donor language" (Riaz \& Khan, 2013, p. 46), language of science and technology and an "indispensable part of advertising discourse" (Zhiganova, 2016, 226), has influenced the lexicon of other languages. People not only employ English expressions out of need but also due to willingness and desire to be associated with the elite and educated class. This impact has led to a world-wide language variation on a large scale. This variation can be evidently observed in the form of code-mixing and code-switching. In case of Urdu language, Ehsan and Aziz (2014) noted that "many words of English language are known and used by people who have never studied the language. Words like plate, glass, television, dressing table, sorry, thank you are frequently used in routine communication without any awareness of code-mixing" (p. 161).

$\mathrm{TV}$ ads are an immensely lucrative way of spreading information, publicizing the products and services as well as affecting the behavior patterns, norms of thinking, styles and linguistic choices; because, they are repeated and broadcasted everyday with the intent of influencing the audience. The audience automatically adopts the suggested products and unconsciously linguistic patterns as well. To win the 'rating scale,' all channels are working in different areas to make the news more interesting and attractive. "In short, all devices are being used by them to satisfy the viewers on the basis of the ground reality that society, language and media are tied in a close relationship" (Rasul, 2006, in Ehsan \& Aziz, 2014, p. 161). As according to Horasan (2014), code-switching "encourages the creative language use" (p. 32), so it's valuable to identify its role in the language of advertising.

The present study aims at analyzing code-switching and code-mixing in the TV ads because these linguistic devices may not only influence the audience but also reflect their linguistic choices. Therefore, it is important to analyze the variation in Urdu due to impact of English. According to Mushtaq and Zahra (2012), Urdu, the national language of Pakistan, is gradually losing its vitality and prestige because English has been embraced as a replacement in various fields. The present study also explores the kind of English words, phrases or sentences that are employed in terms of the nature of words and registers.

\subsection{Literature review}

Various research studies have been carried out on code-mixing and code switching not only in various languages but also in various domains such as code-mixing or code switching in media, profession, advertising, textbooks, literary texts, messaging or online communication etc. Moreover, lexical borrowing from English has been widely studied in relation to other languages. Akinyi (2017) analyzed code-mixing in the purposively selected print advertisements of 3 telecom companies and 6 commercial banks in Kenya and noted that compound lexical items, blend forms, entirely new usage of words and free and bound morpheme combinations were prevalent forms of code-mixing of English and Kiswahili to influence or attract the customers. Zhiganova (2016), by asking 153 German speaking participants to respond to slogans with or without code-switching in TV advertisements, studied the impact of code-switching in German TV adverts; and found that majority of the people preferred slogans in German; while their general response towards the English-inserted slogans was negative implying that the use of English adds to modernity and attractiveness but eliminates authenticity and intelligibility.

Gritsenko (2016) asserted that mixing from English in Russian professional communication was not only a source to "bridge lexical gaps or to convey sociocultural connotations" but also a way to display prestige, quality, reliability, success and innovation (p. 179). Investigating frequency of lexical borrowing in the speech of two groups of Indonesian celebrities, Yuliana et al. (2015) found that the celebrities whose parents were native speakers and the celebrities who could speak multiple languages 
displayed different frequencies of code-mixing and code-switching; however, code-mixing was mostly made in the form of insertion or alternation, while code-switching was made on intersentential rather than extrasentential level by both the groups.

Tina (2015) investigated the code-switching patterns between English and Bengali written on one hundred and thirty five commercial signboards displayed in Dhaka, Bangladesh and found that 13 out of 135 signboards employed pure Bengali names; while the others relied mostly on English to make the names appear stylish, exotic or attractive to the customers. Hasan and Akhand (2015) studied day to day speech of Bangla people and concluded that tag-switching and intrasentential switching of English are more prevalent than code-mixing, which when done, is often phonologically or semantically incorrect. Moreover, various words such as confusion, confirm or urgent are used so frequently that Bangla speakers think that those are words of Bangla. Senaratni (2017) examined 50 bilingual printed and electronic advertisements printed and broadcasted in Sri Lanka from 2015-2016, in order to analyze the use of code-mixing of English and Sinhala, and concluded that the creative writers use nativization, hybridization, nominalization and coinage as morphological processes to develop the content of the advertisements that may appeal the urban bilinguals in the country. Though code-mixing of English is less than $50 \%$, yet the trend shows that English is given much importance which reflects the changing social trends and linguistic choices of Sinhala speakers in Sri Lanka. Vizcaíno (2011) asserted that embedding of unexpected patterns of foreign languages helped create humor in the advertisements of Spanish airlines.

Dimova (2012), after analyzing the functions of English code-switching in four purposively selected Macedonian TV commercials, selected out of 200 commercials, noted that code-mixing and codeswitching between English and Macedonian enhanced the semantic and lexical properties of the commercials, as well as, molded and reconfigured the identities of the consumers. Vizcaíno (2011), Kia et al., (2011), Nandi (2013), Sinhee (2006) and Kandace (2004) carried out research on Spanish, Chinese, Hindi Korean and GermanAds respectively from the point of code-mixing or switching.

Moreover, various researchers such as Awan and Sheeraz (2011), Talat (2002), Riaz and Khan (2013), Humaira (2012), Hsu (2013) also carried out research on different aspects of code-mixing and switching such as gender differences, functions in literature or educational setting and public's attitude towards mixing in advertisements etc. Noor et al., (2015) carried out a semantic analysis of Pakistani commercials ranging over a period of one month and unveiled the "linguistic means to enhance the charismatic appeal" (p. 11). Mushtaq (2012) also analyzed the impact of only code-mixing on the viewers of Pakistani commercials quantitatively with data ranging over three days and questionnaires filled by thirty students on the impact of the commercials and found that code-mixing is prevalent in the commercials and it has positive impact on the viewers because it helps convey the message effectively. Khan (2014) has studied the social functions of code mixing related to gender, class and educational status of the characters in twelve Pakistani TV ads of beauty products; but research is needed on Pakistani TV ads on the basis of both these linguistic devices analyzed in a relatively larger set of data, and the present study will fill this gap.

It is important to note that the study does not intend to degrade or criticize any TV channel, product or TV Ad. It does not aim at challenging or questioning the extent to which English or Urdu is being employed in Pakistani TV ads. It only aims at investigating the frequencies of both the linguistic devices with an intention of analyzing language variation. 


\subsection{Research questions}

- What are the frequencies of code-mixing and code-switching in the TV ads broadcasted in Pakistan?

- What is the nature of borrowed English words?

\subsection{Scope and Significance of the study Method}

Though most of the studies already carried out on borrowing, code-mixing and code-switching in other languages or discourses in general and in Pakistani context in particular, specifically focus on the impact or social functions of the phenomena; yet the present study focuses more on frequency of CM and CS, especially in commercials broadcasted in Pakistan. It analyzes the influence of English on the language of Pakistani TV ads which will help understand the variation caused to Urdu language. It will help sensitize the linguists and media personnel to maintaining certain language policy. It also has significant scope for and relevance to discourse analysis, stylistics, language of media and language policy and planning. It draws attention to the point that many words in Urdu are being substituted by English words even though there are Urdu substitutes available. Though languages evolve naturally and affect one another, yet it is important to analyze the extent to which variation is being made. Therefore, this study reflects how much English has influenced Urdu lexicon over the previous few years.

\subsection{Delimitations of study}

The present study has been delimited to the following commercials and years:

- 70 commercials broadcasted on Pakistani TV channels.

- Commercials broadcasted on ARY Digital, HUM TV and GEO TV during the years 20112015.

\section{Methods}

\subsection{Data collection Procedures}

Seventy commercials which have been broadcasted through different channels during the years 20112015 have been selected through convenience sampling and the frequency of English words has been checked manually. The TV ads that have been on-aired on ARY Digital, HUM TV or GEO TV have been selected as data through downloading the videos of those TV Ads from three websites: Dailymotion, Youtube and YT Pak. Videos have been transcribed and the frequencies of code-mixing and code-switching have been checked. The length of text in different TV ads varies. Cumulatively, the data comprises of 4746 words. TV ads vary in nature and include various products such as cosmetics, house-hold material, electronic appliances, telecommunication companies, digital products and edibles such as biscuits, drinks, and spices etc. Data have been analyzed qualitatively by counting the expressions, checking the percentages and describing in words.

\subsection{Data Analysis}

For data analysis, all English words used in the data were highlighted and counted. The frequencies of English words have been checked separately for code-mixing and code-switching to avoid any overlapping. Words and phrases have been considered as code-mixing and sentences have been taken as code-switching. Moreover, the repeated English words in any particular TV Ad have not been 
considered. Frequencies have been checked through applying the mathematical formula of percentage. Frequencies and the types or words used have been displayed in tabulated form.

The frequency of brand names has been separately checked because the brand names may or may not be proper English words. These brand names have repeatedly been used in numerous TV ads. They may be proper English nouns, acronyms or clippings of English words but at times their origin may not be clearly deciphered. Examples include TUC, Fanta, Dew, Care, PEPSI, Oreo, Dove, Ufone, and Tapal etc. Therefore, their frequency has been checked separately.

\section{Findings and Discussion}

Analysis reveals the following trends:

Table 1. Number of Total and Borrowed Words

\begin{tabular}{ll}
\hline Total number of words in the data & $\mathbf{4 7 4 6}$ \\
Total number of brand names & 147 \\
Total number of borrowed words & $\mathrm{CM}+\mathrm{CS}$ \\
& $871+121$ \\
Total number of times code-switching has been employed & 38 \\
\hline
\end{tabular}

Table 2. Percentages of Code-Mixing and Code-Switching

\begin{tabular}{ll}
\hline Frequencies & \\
Frequency of Code-mixing & $18.35 \%$ \\
Frequency of Code-mixing of Brand/Product Names & $3.09 \%$ \\
Total & 21.44 \\
Frequency of Code-switching & 2.54 \\
Grand Total & 23.98 \\
\hline
\end{tabular}

Table 3. Nature of Borrowed Words

\begin{tabular}{ll}
\hline Words Used & Examples from the data \\
\hline Technology related words & Mobile, refrigerator, engine, cable \\
Numerals & $2500,400,4,5,6$ \\
Abbreviations & SMS, CD, FM, BA \\
Trade and commerce related words & Profit, resale, tax, rates, package \\
Cosmetics and household & fairness, recipe, oil, skin, shopping \\
Adjectives & Strong, unlimited, crispy, cool, soft, stylish \\
New formation/modification & Filmy, motorcyclon, fruttare, talkshawk \\
Verbs & Twist, blend, repair, call, wait, taste \\
\hline
\end{tabular}

The findings given in Table 1 reveal that out of 4746 words in the data 871 words have been codemixed, while 121 have been code-switched. The percentage of code-mixing and code-switching, as given in Table 2, is 18.35 and 2.54 respectively, while that of brand names is $3.09 \%$. Switching on 'inter-sentential' level has been made 38 times. This shows that the frequency of code-switching is lesser than that of code-mixing. Though the frequencies are not very high, yet these are significantly meaningful and note-worthy. Words related to technology, household, cosmetics, and trade and 
commerce have been used in the TV ads. Moreover, English verbs and adjectives have also been employed. English words have also been modified to make new words. Lopes (2002) asserts that the term code mixing is used to describe languages within word boundaries, as a result of which new vocabulary is born (p. 7). In addition, abbreviations and numerals have also been used frequently.

Table 3 shows that words like skin, oil, unlimited, cool, blend, wait, taste, shopping, rates and repair, international, strong, taste, yogurt, light, cooling, offer, drop, clean, list, magnet, sorry, better, job, house etc. do have substitutes in Urdu but they are not being employed due to the innovation, ease and novelty, or what Zhiganova (2016) calls modernity, that English can offer. However, words such as mobile, SMS, CD Innings, runs, sim, mobile, bluetooth and battery etc. used in the data have to be used as such. Nonceformations can also be observed and are important on morphological grounds. Vizcaíno (2011), Kia et al., (2011), Nandi (2013), Sinhee (2006) and Kandace (2004) also found the same results so far as the use of abbreviations, technology related terms and day-to-day use of English words are concerned. Hasan and Akhand (2015) found that the Bangla speakers borrow words from English in day to day conversation yet their choices are often phonologically or semantically incorrect; however, as TV commercials are preplanned, so in the present study, phonologically, deviation may be found according to the regional accent but the choices are not incorrect semantically or phonologically. The findings, in this regard, are similar to those of Senaratni (2017); because the content writers, in an effort to make the language of commercials more effective, have employed nativization and coinage as strategies but not on a large scale. Mostly, English words have been found to be substituting the Urdu words as such without any major morphological make-up. Therefore, the findings are different from Akinyi's (2017) findings regarding kenyan advertisements as well, because though blends and new words have been created, yet English words predominantly retain their form and experiments have not been made with creating nonce-formations. Findings of this study, however, support the findings of Mushtaq (2012) who studied the impact of code-mixing and found that it was prevalent in Pakistani commercials. The present study adds that the frequency of code-mixing is higher in the commercials than code-mixing.

So far as code-switching is concerned, the following has been found:

- Short constructions have been used.

- Declarative, interrogative and imperative constructions have been made.

- Both intersentential and intrasentential code-switching, as well as, tag-switching have been employed but intrasentential are less common. Sometimes, just one word from Urdu is employed as a tag; while in other instances, two independent clauses of Urdu and English have been combined on sentence boundaries. Phrases have also been switched within the boundaries of a sentence. Hasan and Akhand (2015) also found that tag-switching and intersentential code-switching than intrasententional code-switching were more common in day-to-day conversation of Bangla speakers.

Following are the examples of these findings:

- Live it $a b h i$.

- To maan'na he para, it really works.

- Aur saaray conditioners and shampoos are the same.

- Aik lucky winner will meet me at wimbeldon aur 100 fans $k$ sath mil $k$ ho g gapshap.

- Meri chaiy to regular hai just the way I like it.

The use of declarative, interrogative and imperative constructions shows that English is mainly being relied on to communicate purpose. 


\section{Conclusions}

It can be concluded that the language of commercials has changed to a greater extent due to borrowing of English words and sentences. The blurring of boundaries between Urdu and English shows the attitude of speakers to both the languages. Many English words frequently employed do have equivalents in Urdu but, in an effort to make the message more interesting and attention grabbing, those equivalents have not been employed. In order for Urdu to maintain its unique identity, it is important that certain limit be set on the use of English words and specially sentences in it.

\subsection{Suggestions and recommendations:}

Following are the suggestions for further research:

- Research can be carried out with larger set of data.

- Research can be carried out specifically on brand names, nonce formations or repetition in commercials or TV Ads.

The findings of the study can be used while teaching code-mixing and code-switching; because it will help the students learn through what they themselves have experienced viewed or heard on TV. The study also has implications for language policy for media.

\section{References}

Akinyi, A. J. (2017).The patterns of language-mixing in print adverts of commercial banks and mobile telecommunications firms in Kenya. International Journal of Education and Research, 5(5), 27-40.

Awan, S., \& Sheeraz, M. (2011). Gender-oriented code-switching: a study of English language teachers at Pakistani universities. International Journal of Academic Research, 3(4), 410-415.

Crystal, D. (1985). The Cambridge encyclopedia of language. Cambridge University Press: New York.

Dimova, S. (2012). English in Macedonian television commercials. World Englishes, 31(1), 15-29.

Ehsan, A., \& Aziz, S. A. (2014). Code-mixing in Urdu news of a private Pakistani channel.Academic Research International, 5(1), 160-169.

Elena S., \& Gritsenko, E. S. (2016). English as a meaning-making resource in Russian-based professional communication. Procedia - Social and Behavioral Sciences, 236, 174 - 180. DOI:10.1016/j.sbspro.2016.12.061

Horasan, S. (2014). Code-switching in EFL classrooms and the perceptions of the students and teachers. Journal of Language and Linguistic Studies, 10(1), 31-45.

Hsu, J. L. (2013). English mixing in advertising in Taiwan: A study of English-literate readers' attitudes .Concentric: Studies in Linguistics, 39(1), 91-122.

Humaira. (2012). Code switching and code mixing in English classroom. Retrieved from:http://humairahbima.blogspot.com/2012/05/code-switching-and-code-mixingin.html

Kachru. (1986. 8 April 2012 ). Code-mixing, style repertoire and language variation: English in Hindu Poetic creativity. World Englishes. Retrieved from: http://www.edu.utas.edu.au/user//tle/ JOURNAL /issues/2008/24-2pdf 
Kandace, E. (2004). Mixed messages: English in German advertising. Journal of language for international business, 15(1), 41-61.

Kia, L.S. (2011). Code-mixing of English in the entertainment news of Chienese newspapers in Malaysia. International Journal of English Linguistics, 1(1), 3-14.

Khan, A. M. (2014). Social aspects of code-switching: An analysis of Pakistani television advertisements. Information Management and Business Review, 6(6), 269-279.

Lopes, E. I. (2002). English/Spanish code switching in Chicano short fiction. Retrieved on August 12, 2018 from: http://urn.fi/URN:NBN:fi:jyu-2002894967

Mushtaq, H., \& Zahra, T. (2012). An analysis of code-mixing in Pakistani commercials.Language in India, 12, 428-439.

Nandi, S. (2013). The status of English in Indian advertisement. International Journal of Electronics \& Communication Technology, 4 (1), 148-151.

Noor, M., Mustafa, R., Muhabat, F., \& Kazemian, B. (2015). The language of TV commercials' slogans: a semantic analysis. Communication and Linguistics Studies, 1(1), 7-12.

Rasul, S. (2006). Language hybridization in Pakistan as socio-cultural phenomenon: An analysis of Code-mixed linguistic patterns. Retrieved from http://prr.hec.gov.pk/thesis/2426.pdf

Rasul, S. (2013). Borrowing and code mixing in Pakistani children's magazines: practices and functions. Pakistaniaat: A Journal of Pakistan Studies, 5(2), 46-72.

Riaz, M. \& Khan, M. K. (2013). Functions of Codemixing: the adaptation of borrowed words for creating humour in Urdu poetry. Pakistan Journal of Languages and Translation Studies, 2, 45-57.

Senaratne, C. D. (2017). Creativity in the use of Sinhala and English in advertisements in Sri Lanka: A morphological analysis. International Journal of Cognitive and Language Sciences, 11(1), 7-12.

Shinhee, L. J. (2006). Linguistic constructions of modernity: English mixing in Korean television commercials. Language in Society, 35, 59-91.

Shooshtari, Z. G., \& Allahbakhsh, M. (2013). Mixing English in Persian print advertising discourse. International Journal of Society, Culture \& Language, 1(2), 82-103.

Skiba, R. (1997). Code switching as a countenance of language interference, The Internet TESL Journal, 3(10).

Tina, A. A. (2015). Bengali - English code - switching in commercial signboards in Bangladesh. Retrieved on July 7, 2018 from: http://hdl.handle.net/20.500.11948/1161

Vizcaíno, M. J. G. (2011). Humour in code-mixed airline advertising. Pragmatics, 21(1), 145-170.

Yuliana, N., Luziana, A. R., \& Sarwendah, P. (2017). Code-mixing and code-switching of Indonesian celebrities: a comparative study. Jurnal Lingua Cultura, 9 (1), 47-54.

Zhiganova, A. V. (2016). The study of the perception of code-switching to English in German advertising. Procedia - Social and Behavioral Sciences, 236, 225 - 229.

DOI:10.1016/j.sbspro.2016.12.011 


\section{Dil değişimi: Pakistan reklamlarında kod karıştırma ve kod değiştirme}

$\ddot{O} \mathbf{z}$

Uluslararası bir dil olarak İngilizce, dünyada konuşulan tüm diller üzerindeki etkisini bıraktı. Bu etki büyük ölçüde dünya çapında bir dil değişikliğine neden olmuştur. Bu değişim açıkça kod karıştırma ve kod değiştirme şeklinde görülebilir. Bu çalışma, Urduca'da İngilizce'ye bağlı olarak meydana gelen değişkenlik seviyesini belirlemek için Pakistan'da yayınlanan TV reklamlarında kod karıştırma sıklığını araştırıyor ve analiz ediyor. 2011-2015 yıllarında gösterilen yetmiş reklam rastgele seçilmiş ve İngilizce kelimelerin sıklı̆̆ı kontrol edilmiştir. Sonuçlar, reklamların dili ile ilgili olarak, Urducanın moda, kolaylık ve teknolojik gelişmeler vb. Gibi çeşitli nedenlerden dolayı İngilizceden açıkça etkilendiğini göstermektedir.

Anahtar sözcükler: dil değişimi; ticari; Kod-karıştırılmasi; kod değişimi

\section{AUTHOR BIODATA}

Ms Mehvish Riaz is working as an Assistant Professor at the University of Engineering and Technology, Lahore, Pakistan. Her research interests include Sociolinguistics, SLA, ELT, ESP, Stylistics and Discourse Analysis. 